\title{
USE OF ALGAE IN ACTIVE BIOMONITORING OF SURFACE WATERS
}

\author{
ZASTOSOWANIE GLONÓW W BIOMONITORINGU AKTYWNYM \\ WÓD POWIERZCHNIOWYCH
}

\begin{abstract}
Biomonitoring studies have been carried out in three retention reservoirs located in the Opole Province (southern Poland): Turawa reservoir, Nysa reservoir and Otmuchow reservoir. The increases of concentrations of $\mathrm{Mn}, \mathrm{Fe}, \mathrm{Cu}, \mathrm{Zn}, \mathrm{Cd}$ and $\mathrm{Pb}$ in fresh water algae Spirogyra sp. and sea water Palmaria palmata (Linnaeus) Weber $\&$ Mohr, exposed in the analysed waters, were determined by the atomic absorption spectrometry method (AAS). Also the waters $\mathrm{pH}$, conductivity and $\mathrm{Mn}$ and $\mathrm{Fe}$ concentrations were determined. The concentrations of $\mathrm{Cu}, \mathrm{Zn}$, $\mathrm{Cd}$ and $\mathrm{Pb}$ in the analysed waters were lower than the method limit of determination. The analyses were carried out during the period from June to July 2014. The differences between the increases of heavy metal concentrations in the samples of algae found along the coastline were indicated; they result from different distances from the pollution sources, such as sediments or drainage from the areas adjacent to the reservoirs. Better sorption characteristics of Palmaria palmata in comparison to Spirogyra sp. were indicated. An empirical interrelation was also tested, the application of which after modification may enable the quantitative assessment of waters pollution with heavy metals, based on the analysis of the concentration of the element in the algae thallus.
\end{abstract}

Keywords: algae, Spirogyra sp., Palmaria palmata (Linnaeus) Weber \& Mohr, heavy metals, biomonitoring, retention reservoirs

\section{Introduction}

The influence of environmental pollution on living organisms has been known for many years; however, methodical studies of the influence of anthropopressure on the changes happening in ecosystems were initiated as late as in the second half of the 20th century. Living organisms became to be used as biological indicators of environmental pollution. A group of methods was defined, which use the abilities of certain organisms to accumulate pollution. Cyclic and quantitative analyses of pollution concentration in bioaccumulators became the foundation of the modern environmental pollution biomonitoring.

The biomonitoring studies of surface waters most frequently use algae, which have very good sorption characteristics and adapt very well to various environments [1-3].

\footnotetext{
${ }^{1}$ Independent Chair of Biotechnology and Molecular Biology, Opole University, ul. kard. B. Kominka 6, 45-032 Opole, Poland, phone +48 774016042

*Corresponding author: mrajfur@o2.pl
} 
Algae are thalloid plants. Among them, except for eukaryotes (ie Spirogyra sp. and Palmaria palmata), there are groups of organism with prokaryotic cells (cyanobacteria). Their thallus has a complex morphological structure (unicellular and multicellular organism, types forming colonies) and various shapes (from dimensions in $\mu \mathrm{m}$, as well as large, leave-like forms) [4-6].

Biomonitoring studies with the use of algae are carried out by passive methods (passive biomonitoring), during which algae present in natural environment are analysed [7-12] and active methods (active biomonitoring), during which algae, living in environments with little pollution, are transferred to and exposed in the ecosystems with higher pollution levels, eg heavy metals [13].

Biomonitoring studies with the use of algae have been carried out in, among others, Poland (the Turawa reservoir, the Odra river, Baltic Sea) [14-17], in Czech Republic (the Dyje river) [18], Russian Federation (12 rivers in the Kola Peninsula, the Yenisey river in Siberia, Lake Baikal, the Sea of Japan) [19-22], China (the South China Sea waters near the Hong Kong island) [23, 24], Portugal (waters of Ria de Aveiro lagoon) [25], Argentina (the lakes in the Andes: Nahuel Huapi, Gutirrez and Moscardi) [26], Uganda (Lake George, a stream near the city of Kampala) [27, 28] and in Nigeria (the Niger river) [29].

The studies carried out with the use of sea and fresh water algae confirm their practical application not only in biomonitoring of surface waters pollution [14-29] but also waters phytoremediation [30] and as biosorbents in the effluent treatment process [31].

Some instrumental methods of water chemical composition, eg atomic absorption spectrometry (AAS), require concentrating of water samples in order to determine the trace quantities of heavy metals. Algae offer an alternative solution. Thanks to their very good sorption characteristics [3], in solutions after mineralisation, a much higher metals concentration is obtained compared to concentrations of these metals in water. Determining the correlation between concentrations of analytes in algae and water can be used to prepare a simple method for determination of heavy metals concentration in surface waters, on the basis of the chemical analysis of the algae thallus composition.

The objective of the studies was to apply active biomonitoring to determine the distribution of bioaccessible forms of heavy metals: $\mathrm{Mn}, \mathrm{Fe}, \mathrm{Cu}, \mathrm{Zn}, \mathrm{Cd}$ and $\mathrm{Pb}$ along the coastline of the retention reservoirs: Turawa, Nysa and Otmuchow and demonstrate heterogeneity of the distribution of analytes concentrations in the studied reservoirs resulting, among others, from the distance from pollution sources. The algae Spirogyra sp. and Palmaria palmata were used in the study and exposed in the studied reservoirs. The study also included the possibility to use sea algae for the purpose of quantitative determination of bioaccessible forms of manganese in surface waters.

\section{Characteristics of the research field}

The Turawa reservoir with the area of 2.2 thousand hectares is located within the Protected Landscape Park Stobrawsko-Turawskie Woodland, approximately $20 \mathrm{~km}$ north-south from Opole. The artificial lake was built during the years 1933-1938. The reservoir was created by damming up the waters of the Mala Panew river. There are two pumping stations at the reservoir: in Jedlice and Szczedrzyk, which discharge surface waters from fields and ditches to the lake [32]. 
The reservoirs Otmuchow (area 2.03 thousand hectares) and Nysa (area 2.13 thousand hectares) are located in the Otmuchow-Nysa Protected Landscape Park. They are located approximately $60 \mathrm{~km}$ south-west from Opole. Together with the Topola and Kozielno reservoirs, they were built along a $30 \mathrm{~km}$ long section of the Nysa Klodzka river as a flood control system. The Otmuchow reservoir was built during the period from 1928 to 1933 and the Nysa reservoir was completed in 1971.

Due to much diversity, the reservoirs are home to numerous rare and protected species of plants and animals [33]. They are favoured recreation areas for the inhabitants of Opole Province and neighbouring regions. The reservoirs are protected under the Natura 2000 program (The Birds Directive) [34].

\section{Materials and methods}

Fresh water algae Spirogyra sp., sampled from relatively clean waters in a reservoir located in a closed gravel pit in Opole town, and sea water algae Palmaria palmata (Linnaeus) Weber \& Mohr purchased from the company Bogutyn Mlyn in Radzyn Podlaski (PL), were used during the study. The fresh water algae, after cleaning from plant and other impurities, were rinsed with demineralised water (conductivity $\kappa=0.5 \mu \mathrm{S} / \mathrm{cm}$ ). The cleaned samples were dehydrated by freeze-drying at the temperature of $223 \mathrm{~K}$ for 20 hours. Such prepared algae were stored in tightly closed polyethylene containers.

The sea algae were purchased dried. In order to remove the salts released in consequence of destruction of cell membranes, the algae were rinsed with demineralised water and dried for 24 hours at the temperature of $323 \mathrm{~K}$. The algae prepared in this way were stored for further analyses.

The concentrations of metals naturally accumulated in the dry mass of Spirogyra sp. amounted to the following: $c_{M n, 0}=22.60 \pm 0.04 \mathrm{mg} / \mathrm{kg} \mathrm{d.m}$. (d.m. - dry mass); $c_{F e, 0}=72.61$ $\pm 0.18 \mathrm{mg} / \mathrm{kg}$ d.m.; $c_{C u, 0}=1.24 \pm 0.05 \mathrm{mg} / \mathrm{kg}$ d.m.; $c_{Z n, 0}=9.12 \pm 0.03 \mathrm{mg} / \mathrm{kg}$ d.m.; $c_{C d, 0} \leq 0.81 \mathrm{mg} / \mathrm{kg}$ d.m.; $c_{P b, 0} \leq 4.38 \mathrm{mg} / \mathrm{kg}$ d.m. Whereas in Palmaria palmata, the concentrations of metals naturally accumulated in the thallus amounted to: $c_{M n, 0}=615 \pm 13 \mathrm{mg} / \mathrm{kg} \mathrm{d.m}$.; $c_{F e, 0}=966 \pm 18 \mathrm{mg} / \mathrm{kg} \mathrm{d.m}$.; $c_{C u, 0}=4.32 \pm 0.08 \mathrm{mg} / \mathrm{kg}$ d.m.; $c_{Z n, 0}=32.7 \pm 0.1 \mathrm{mg} / \mathrm{kg} \mathrm{d}$.m.; $c_{C d, 0} \leq 0.81 \mathrm{mg} / \mathrm{kg} \mathrm{d.m}$.; $c_{P b, 0} \leq 4.38 \mathrm{mg} / \mathrm{kg} \mathrm{d.m}$.

The representative (averaged) algae samples with the mass of $1 \mathrm{~g} \mathrm{~d} . \mathrm{m}$. were placed in perforated polyethylene containers of capacity ca $15 \mathrm{~cm}^{3}$. Prior to exposition, algae were immersed for $15 \mathrm{~min}$ in demineralised water, in order to activate sorption centres [35]. Next, samples were exposed in waters of the studied reservoirs for $50 \mathrm{~min}$. The samples were immersed in water approximately 1 meter from the shore, in littoral zone. The study included five repetitions. Simultaneously, water samples were taken in the defined measuring spots, in order to determine physical and chemical parameters $(\mathrm{pH}$ and conductivity) and heavy metals concentrations.

Figure 1 presents the map of measuring spots locations.

After exposition, algae samples were rinsed with demineralised water and dried at the temperature of $323 \mathrm{~K}$. The algae samples (dry mass each of them was $0.400 \pm 0.001 \mathrm{~g}$ ) were mineralised in the mixture of nitric(V) acid and hydrochloric acid $\left(\mathrm{HNO}_{3} 65 \%: \mathrm{HCl} 37 \%=1: 3\right)$ using a Speedwave Four by Berghof, DE microwave oven. The mineralization process temperature was $180^{\circ} \mathrm{C}$. MERCK company reagents were used to prepare solutions. Heavy metals $(\mathrm{Mn}, \mathrm{Fe}, \mathrm{Cu}, \mathrm{Zn}, \mathrm{Cd}$ and $\mathrm{Pb}$ ) in mineralised algae 
samples were determined by atomic absorption spectrometry method (AAS), using the equipment iCE 3000 made by Thermo Electron Corporation (USA).

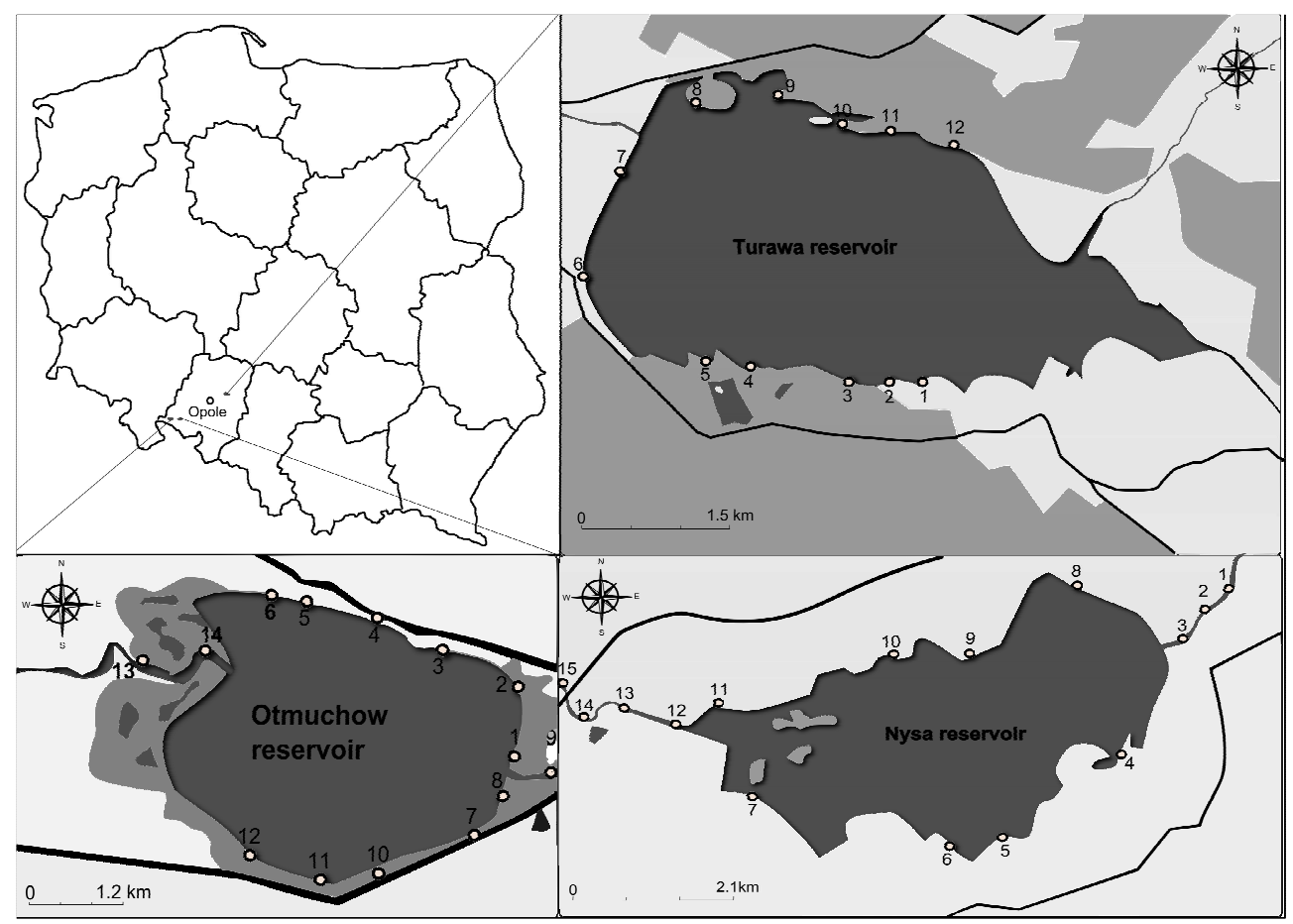

Fig. 1. Measuring spots locations

The water samples, in which heavy metals were determined by the AAS method, were transferred to the filtering system and next acidified with $1 \mathrm{~cm}^{3}$ of the concentrated nitric $\operatorname{acid}(\mathrm{V})$.

The conductivity and $\mathrm{pH}$ of the water, in which algae were immersed, were measured with the equipment made by Elmetron Sp.j. from Zabrze (PL): pH meter CP 401, which absolute measurement error was $\Delta \mathrm{pH}=0.02$ and $\Delta \kappa=0.1 \mu \mathrm{S} / \mathrm{cm}$, respectively.

\section{Quality and quality assurance}

Table 1 presents the limits of detection and the limits of quantification of heavy metals for the spectrometer iCE 3500 [36]. Calibration of spectrometer was performed with a standard solution from ANALYTIKA Ltd. (Czech Republic). The values of the highest concentrations of the models used for calibration $\left(2 \mathrm{mg} / \mathrm{dm}^{3}\right.$ for $\mathrm{Cd}, 5 \mathrm{mg} / \mathrm{dm}^{3}$ for $\mathrm{Cu}, \mathrm{Zn}$, $\mathrm{Pb}, 7.5 \mathrm{mg} / \mathrm{dm}^{3}$ for $\mathrm{Mn}$ and $10 \mathrm{mg} / \mathrm{dm}^{3}$ for $\mathrm{Fe}$ ) ware approved as linear limits of the signal dependence on the concentration.

Table 2 shows heavy metals concentrations, determined in the certified reference materials as BCR-414 plankton and BCR-482 lichen, prepared by the Institute for Reference Materials and Measurements, Belgium. 
The instrumental detection limits $(I D L)$ and instrumental quantification limits $(I Q L)$

Table 1 for the spectrometer iCE $3500\left[\mathrm{mg} / \mathrm{dm}^{3}\right][36]$

\begin{tabular}{|c|c|c|}
\hline Metal & IDL & IQL \\
\hline $\mathrm{Mn}$ & 0.0016 & 0.020 \\
\hline $\mathrm{Fe}$ & 0.0043 & 0.050 \\
\hline $\mathrm{Cu}$ & 0.0045 & 0.033 \\
\hline $\mathrm{Zn}$ & 0.0033 & 0.010 \\
\hline $\mathrm{Cd}$ & 0.0028 & 0.013 \\
\hline $\mathrm{Pb}$ & 0.0130 & 0.070 \\
\hline
\end{tabular}

Comparison of measured and certified concentrations in BCR-414 plankton and in BCR-482 lichen

\begin{tabular}{|c|c|c|c|c|c|}
\hline \multirow{3}{*}{ Metal } & \multicolumn{2}{|c|}{ BCR-414 plankton } & \multicolumn{2}{|c|}{ AAS } & \multirow{2}{*}{ Dev.** } \\
\hline & Concentration & \pm Uncertainty & Average & $\pm S D^{*}$ & \\
\hline & \multicolumn{4}{|c|}{$[\mathrm{mg} / \mathrm{kg}$ d.m. $]$} & {$[\%]$} \\
\hline $\mathrm{Mn}$ & 299 & 12 & 284 & 13 & -5.0 \\
\hline $\mathrm{Fe}$ & 1.85 & 0.19 & 1.79 & 0.20 & -3.2 \\
\hline $\mathrm{Cu}$ & 29.5 & 1.3 & 28.4 & 1.6 & -3.7 \\
\hline $\mathrm{Zn}$ & 112 & 3 & 107 & 3 & -4.5 \\
\hline $\mathrm{Cd}$ & 0.383 & 0.014 & n.d. & n.d. & n.d. \\
\hline $\mathrm{Pb}$ & 3.97 & 0.19 & 3.75 & 0.21 & -5.5 \\
\hline \multirow{3}{*}{ Metal } & \multicolumn{2}{|c|}{ BCR-482 lichen } & \multicolumn{2}{|c|}{ AAS } & \multirow{2}{*}{ Dev.** } \\
\hline & Concentration & \pm Uncertainty & Average & $\pm S D^{*}$ & \\
\hline & \multicolumn{4}{|c|}{ [mg/kg d.m.] } & {$[\%]$} \\
\hline $\mathrm{Mn}$ & 33.0 & 0.5 & 31.7 & 0.68 & -3.9 \\
\hline $\mathrm{Fe}$ & 804 & 160 & n.d. & n.d. & n.d. \\
\hline $\mathrm{Cu}$ & 7.03 & 0.19 & 6.63 & 0.17 & -5.7 \\
\hline $\mathrm{Zn}$ & 100.6 & 2.2 & 95.1 & 2.3 & -5.5 \\
\hline $\mathrm{Cd}$ & 0.56 & 0.02 & 0.53 & 0.03 & -5.3 \\
\hline $\mathrm{Pb}$ & 40.9 & 1.4 & 38.2 & 1.0 & -6.6 \\
\hline
\end{tabular}

* - standard deviation, $* *$ - relative difference between the measured and certified concentration $100 \% \cdot\left(c_{\mathrm{z}}-c_{\mathrm{c}}\right) / c_{\mathrm{c}}$ n.d. - not determined

\section{Results interpretation method}

The increases of analytes concentrations in algae, indicating waters pollution, were determined on the basis of the relative accumulation factor (RAF - Relative Accumulation Factor) [14]:

$$
R A F=\frac{c_{(a, 1)}-c_{(a, 0)}}{c_{(a, 0)}}
$$

where: $c_{(a, 0)}$ - mean concentration of the analyte in algae before the exposition [mg/kg d.m.], $c_{(a, 1)}$ - mean concentration of the analyte in algae after the exposition [mg/kg d.m.].

In order to assess accumulation properties of the used algae, the bioconcentration factor (BCF - Bioconcentration factor) was determined, indicating the increase of analytes concentration in algae versus analytes concentration in water $[37,38]$ :

$$
B C F=\frac{c_{(a, 1)}-c_{(a, 0)}}{c_{(s)}}
$$

where $c_{(\mathrm{s})}$ - mean concentration of metal in water $\left[\mathrm{mg} / \mathrm{dm}^{3}\right]$. 
Concentrations of manganese in water and the exposed algae Palmaria palmata were compared, with the use of the empirical correlation determined on the basis of the results of laboratory tests, carried out in order to assess the influence of water conductivity on the changes of algae sorption capacity:

$$
c^{*}{ }_{M g, s}=\frac{0.009 \cdot \kappa+0.46}{1 / c^{*}{ }_{M n, a}-25}
$$

where: $c_{M n, s}^{*}$ - concentration of manganese in water, $c^{*}{ }_{M n, a}$ - concentration of manganese in algae after exposition.

Concentration of manganese cations was expressed as: $c^{*}=z \cdot c$, where $z$ - cation valence (a dimensionless number), $c$ - concentration expressed in $\left[\mathrm{mmol} / \mathrm{dm}^{3}\right]$ or $[\mathrm{mmol} / \mathrm{g}]$. Numerical factors were determined from Langmuir's isotherms shown in Figure 2.

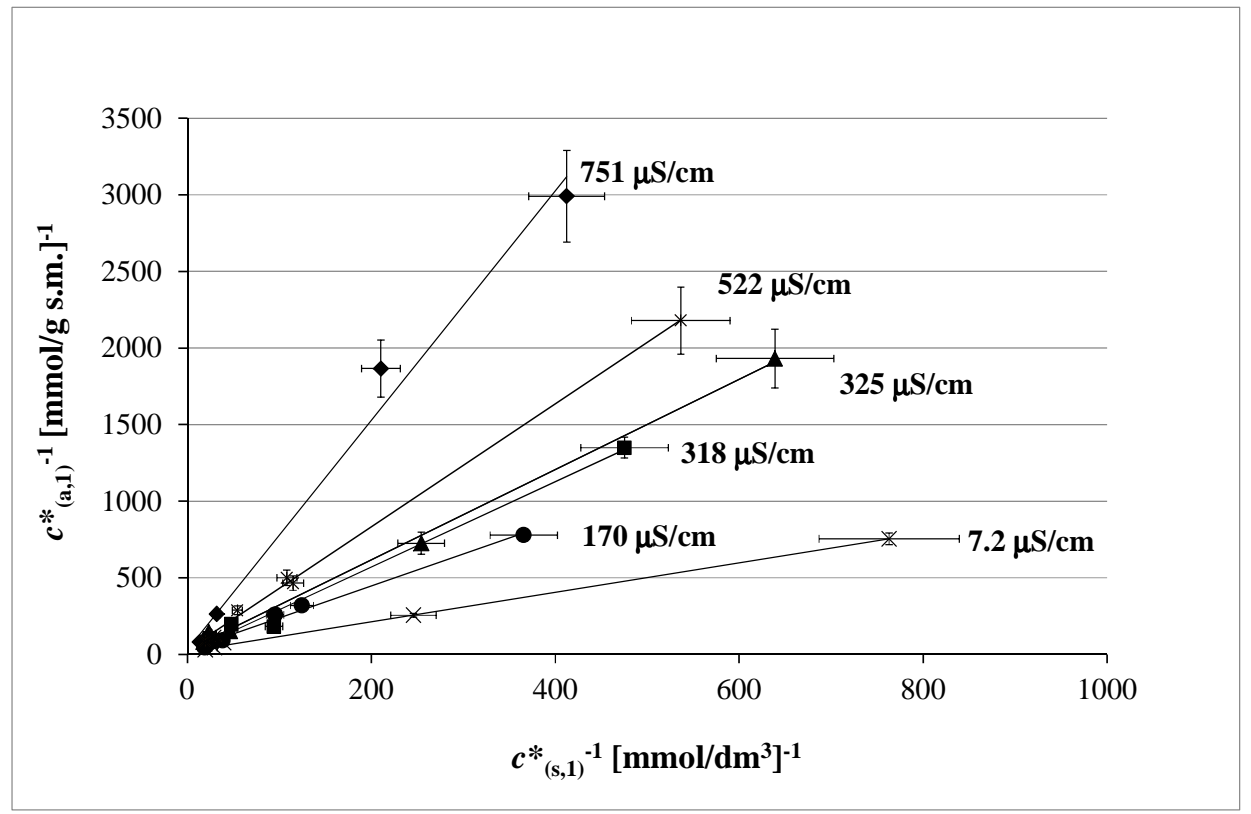

Fig. 2. Influence of ions present in surface waters on $\mathrm{Mn}^{2+}$ sorption in Palmaria palmata

Using parameters of the isotherms presented in Figure 2, a linear correlation $y=0.009 x+0.46$ was determined, describing the changes of the slope of $(y)$, depending on the solution conductivity $(x)$. The value of 25 shown in correlation 3 is the mean of the absolute terms from Langmuir's isotherms. Manganese was selected due to its relatively large, easy to determine, concentrations in surface waters.

\section{Results and discussion}

In Table 3 mean values of physiochemical parameters of water samples taken from different measuring spots, as well as the value of standard deviation from the measurements are presented. 
The results of measurements of physicochemical parameters of the water samples

\begin{tabular}{|c|c|c|c|}
\hline \multirow{2}{*}{ Reservoir } & Parameter & $\mathbf{p H}$ & $\begin{array}{c}\text { Conductivity } \\
{[\boldsymbol{\mu S} / \mathbf{c m}]}\end{array}$ \\
\hline \multirow{3}{*}{ Turawa } & Mean & 8.64 & 351 \\
\cline { 2 - 4 } & Minimum & 8.40 & 261 \\
\cline { 2 - 4 } & Maximum & 8.97 & 387 \\
\cline { 2 - 4 } & $\pm S D$ & 0.20 & 34.6 \\
\hline \multirow{4}{*}{ Otmuchow } & Mean & 9.48 & 263 \\
\cline { 2 - 4 } & Minimum & 8.81 & 242 \\
\cline { 2 - 4 } & Maximum & 10.8 & 278 \\
\cline { 2 - 4 } & $\pm S D$ & 0.58 & 29.80 \\
\hline \multirow{5}{*}{ Nysa } & Mean & 10.1 & 235 \\
\cline { 2 - 4 } & Minimum & 9.11 & 348 \\
\cline { 2 - 4 } & Maximum & 11.0 & 39.4 \\
\cline { 2 - 4 } & $\pm S D$ & 0.63 & \\
\cline { 2 - 4 } & & & \\
\hline
\end{tabular}

Large $\mathrm{pH}$ values (> 9) may signify the progressing eutrophication of the studied reservoirs. The most favourable $\mathrm{pH}$ values of water were determined in Turawa reservoir. A significant improvement compared to previous years $(\mathrm{pH}>10)$ is probably the result of several years of works on installing sewage systems in the localities along the Mala Panew river catchment area. The results of water conductivity measurements signify a comparable salinity of the studied reservoirs.

Table 4 contains the results of measurements of heavy metals concentrations in water samples taken in algae exposition locations.

Table 4

Results of heavy metals concentrations measurements $\left[\mathrm{mg} / \mathrm{dm}^{3}\right]$ in water samples taken in algae exposition locations

\begin{tabular}{|c|c|c|c|c|c|c|c|}
\hline Reservoir & Parameter & Mn & $\mathbf{F e}$ & $\mathrm{Cu}$ & $\mathbf{Z n}$ & Cd & $\mathbf{P b}$ \\
\hline \multirow{3}{*}{ Turawa } & Mean & 0.129 & 0.372 & \multirow{3}{*}{$<0.033$} & $<0.014$ & \multirow{3}{*}{$<0.013$} & \multirow{3}{*}{$<0.07 \mathrm{C}$} \\
\hline & Minimum & 0.022 & 0.149 & & $<0.010$ & & \\
\hline & Maximum & 0.223 & 1.342 & & 0.023 & & \\
\hline \multirow{3}{*}{ Otmuchow } & Mean & $<0.025$ & $<0.126$ & \multirow{3}{*}{$<0.033$} & $<0.013$ & \multirow{3}{*}{$<0.013$} & $<0.186$ \\
\hline & Minimum & $<0.020$ & $<0.050$ & & $<0.010$ & & $<0.070$ \\
\hline & Maximum & 0.068 & 0.634 & & 0.023 & & 1.54 \\
\hline \multirow{3}{*}{ Nysa } & Mean & $<0.059$ & $<0.145$ & \multirow{3}{*}{$<0.033$} & $<0.014$ & \multirow{3}{*}{$<0.013$} & \multirow{3}{*}{$<0.070$} \\
\hline & Minimum & $<0.020$ & $<0.050$ & & $<0.010$ & & \\
\hline & Maximum & 0.177 & 0.701 & & 0.065 & & \\
\hline
\end{tabular}

The analysis of water samples shows that, as far as the average content of $\mathrm{Zn}$ and $\mathrm{Cu}$ is concerned, the water sampled from the three studied reservoirs is below the limit values defined for the 1st and 2nd quality class of surface waters $\left(\mathrm{Zn}<1 \mathrm{mg} / \mathrm{dm}^{3}\right.$; $\left.\mathrm{Cu}<0.05 \mathrm{mg} / \mathrm{dm}^{3}\right)$ [39]. In the case of lead, exceeding the limit values $\left(0.0072 \mathrm{mg} / \mathrm{dm}^{3}\right)$, larger than the method determination limit, was confirmed in Otmuchow reservoir. The FAAS method determination limits make it impossible to asses cadmium content in waters; its maximum permissible concentration, for hardness not more than $40 \mathrm{mg} \mathrm{CaCO} / \mathrm{dm}^{3}$, is $0.00045 \mathrm{mg} / \mathrm{dm}^{3}$ [39]. In most cases, the FAAS method allows to determine directly manganese and iron in surface waters. 
Algae was used in the next stage, in order to determine the differences in concentrations of the analysed metals. As mentioned before, thanks to their very good sorption characteristics, in solutions after mineralisation a much higher metals concentration is obtained, compared to concentrations of these metals in water.

In order to determine uncertainty of the measurement method, algae samples were analysed five times, maintaining the whole cycle of the research method. For the samples of Spirogyra sp. and Palmaria palmata exposed in the defined measurement spots, the value of coefficient of variation $C V_{\text {sr }}$ (Coefficient of variation), determined on the basis of the value of standard deviation $S D\left(C V_{\text {Mean. }}[\%]=1 / 3 \cdot \sum\left(S D_{i} / c_{x, \text { Mean }, i}\right) \cdot 100 \%\right.$, where: $S D_{\mathrm{i}} / c_{x, \text { Mean, } i}$ is a standard deviation calculated for the $i$-series $(i=12 ; 15 ; 14)$, referred to the mean value from that series $\left(c_{x, \text { Mean }, i}\right)$ and, for fresh water algae, is within $18-21 \%$, and for sea water algae, within $12-16 \%$.

Table 5 presents mean concentrations of heavy metals determined in the samples of Spirogyra sp. and Palmaria palmata, exposed in the studied reservoirs.

Table 5

Concentrations of heavy metals in algae Spirogyra sp. and Palmaria palmata $[\mathrm{mg} / \mathrm{kg}$ d.m.]

\begin{tabular}{|c|c|c|c|c|c|c|}
\hline Spot no. & Mn & $\mathbf{F e}$ & $\mathbf{C u}$ & $\mathbf{Z n}$ & Cd & $\mathbf{P b}$ \\
\hline \multicolumn{7}{|c|}{ Turawa reservoir - Spirogyra sp. / Palmaria palmata } \\
\hline 1 & $9.34 / 35.2$ & $22.0 / 190$ & $3.95 / 24.1$ & $5.94 / 44.5$ & $<0.81 /<0.81$ & $7.51 / 4.61$ \\
\hline 2 & $9.82 / 46.7$ & $6.14 / 157$ & $1.06 / 5.17$ & $6.11 / 31.8$ & $<0.81 /<0.81$ & $5.68 / 8.34$ \\
\hline 3 & $11.5 / 96.7$ & $27.1 / 174$ & $0.93 / 3.67$ & $1.25 / 27.3$ & $<0.81 /<0.81$ & $18.2 /<4.38$ \\
\hline 4 & $9.50 / 80.1$ & $10.5 / 198$ & $1.47 / 4.03$ & $2.49 / 34.6$ & $<0.81 /<0.81$ & $6.56 /<4.38$ \\
\hline 5 & $9.98 / 51.0$ & $17.4 / 181$ & $1.58 / 4.47$ & $3.32 / 34.5$ & $<0.81 /<0.81$ & $6.09 /<4.38$ \\
\hline 6 & $9.29 / 175$ & $6.58 / 318$ & $0.60 / 3.98$ & $0.21 / 55.9$ & $<0.81 /<0.81$ & $5.96 / 6.19$ \\
\hline 7 & $38.5 / 56.2$ & $14.1 / 205$ & $1.28 / 3.06$ & $6.94 / 26.6$ & $<0.81 /<0.81$ & $8.51 / 6.76$ \\
\hline 8 & $10.3 / 54.5$ & $15.0 / 335$ & $1.34 / 4.49$ & $3.90 / 36.3$ & $<0.81 /<0.81$ & $22.4 /<4.38$ \\
\hline 9 & $14.3 / 42.6$ & $15.0 / 166$ & $1.44 / 3.55$ & $5.76 / 25.7$ & $<0.81 /<0.81$ & $7.83 /<4.38$ \\
\hline 10 & $11.5 / 203$ & $19.8 / 336$ & $2.61 / 4.34$ & $4.69 / 51.3$ & $<0.81 /<0.81$ & $22.6 /<4.38$ \\
\hline 11 & $9.99 / 29.8$ & $18.1 / 140$ & $1.05 / 2.91$ & $9.58 / 22.7$ & $<0.81 /<0.81$ & $7.21 / 7.03$ \\
\hline 12 & $10.3 / 107$ & $26.2 / 260$ & $2.45 / 3.44$ & $10.4 / 47.1$ & $<0.81 /<0.81$ & $18.6 / 18.5$ \\
\hline Mean & $12.9 / 81.5$ & $16.5 / 222$ & $1.65 / 5.60$ & $5.05 / 36.5$ & $<0.81 /<0.81$ & $11.4 /<6.48$ \\
\hline $\pm S D$ & $8.18 / 55.8$ & $6.76 / 71.6$ & $0.93 / 5.86$ & $3.08 / 10.8$ & $-/-$ & $6.83 /-$ \\
\hline \multicolumn{7}{|c|}{ Otmuchow reservoir - Spirogyra sp. / Palmaria palmata } \\
\hline 1 & $14.7 / 7.01$ & $11.7 / 187$ & $2.06 / 4.89$ & $9.08 / 26.4$ & $<0.81 /<0.81$ & $<4.38 /<4.38$ \\
\hline 2 & $8.52 / 22.7$ & $\mathrm{bp} / 187$ & $1.67 / 4.64$ & $18.0 / 23.4$ & $<0.81 /<0.81$ & $<4.38 /<4.38$ \\
\hline 3 & $12.8 / 28.6$ & bp / 178 & $0.84 / 4.77$ & $7.98 / 24.5$ & $<0.81 /<0.81$ & $<4.38 /<4.38$ \\
\hline 4 & $10.9 / 44.9$ & bp / 356 & $1.82 / 4.68$ & $14.1 / 29.6$ & $<0.81 /<0.81$ & $<4.38 /<4.38$ \\
\hline 5 & $11.9 / 41.3$ & $4.64 / 511$ & $0.15 / 4.45$ & $17.3 / 25.3$ & $<0.81 /<0.81$ & $<4.38 /<4.38$ \\
\hline 6 & $11.1 / 28.6$ & $12.6 / 232$ & $0.59 / 4.90$ & $5.46 / 29.1$ & $<0.81 /<0.81$ & $<4.38 /<4.38$ \\
\hline 7 & $5.73 / 32.0$ & $\mathrm{bp} / 238$ & $1.03 / 5.82$ & $22.0 / 33.5$ & $<0.81 /<0.81$ & $<4.38 /<4.38$ \\
\hline 8 & $6.09 / 26.2$ & $10.0 / 123$ & $0.94 / 4.57$ & $26.4 / 26.3$ & $<0.81 /<0.81$ & $<4.38 /<4.38$ \\
\hline 9 & $0.22 / 12.7$ & $42.1 / 167$ & $2.53 / 4.60$ & $5.75 / 24.4$ & $<0.81 /<0.81$ & $<4.38 /<4.38$ \\
\hline 10 & $9.59 / 18.0$ & $15.9 / 97.9$ & $0.98 / 4.39$ & $6.47 / 24.8$ & $<0.81 /<0.81$ & $<4.38 /<4.38$ \\
\hline 11 & $8.50 / 18.1$ & $37.2 / 121$ & $0.68 / 3.90$ & $10.8 / 21.1$ & $<0.81 /<0.81$ & $<4.38 /<4.38$ \\
\hline 12 & $7.12 / 25.1$ & $8.31 / 164$ & $1.04 / 3.61$ & $10.8 / 24.2$ & $<0.81 /<0.81$ & $<4.38 /<4.38$ \\
\hline 13 & $6.22 / 21.9$ & $20.8 / 107$ & $1.06 / 3.81$ & $8.48 / 23.5$ & $<0.81 /<0.81$ & $<4.38 /<4.38$ \\
\hline 14 & $4.57 / 28.9$ & $10.7 / 157$ & $1.95 / 3.98$ & $7.78 / 24.3$ & $<0.81 /<0.81$ & $<4.38 /<4.38$ \\
\hline Mean & $8.42 / 25.4$ & $17.4 / 202$ & $1.24 / 4.50$ & $12.2 / 25.7$ & $<0.81 /<0.81$ & $<4.38 /<4.38$ \\
\hline $\pm S D$ & $3.79 / 10.2$ & $12.5 / 111$ & $0.66 / 0.56$ & $6.48 / 3.14$ & $-1-$ & $-1-$ \\
\hline
\end{tabular}




\begin{tabular}{|c|c|c|c|c|c|c|}
\hline Spot no. & Mn & $\mathbf{F e}$ & $\mathbf{C u}$ & Zn & Cd & $\mathbf{P b}$ \\
\hline \multicolumn{7}{|c|}{ Nysa reservoir - Spirogyra sp. / Palmaria palmata } \\
\hline 1 & $\mathrm{bp} / 25.2$ & $77.6 / 184$ & $3.10 / 5.67$ & $11.3 / 21.9$ & $<0.81 /<0.81$ & $5.22 /<4.38$ \\
\hline 2 & $\mathrm{bp} / 22.9$ & $13.2 / 169$ & $3.05 / 4.65$ & $22.9 / 23.0$ & $<0.81 /<0.81$ & $10.1 /<4.38$ \\
\hline 3 & bp / 25.4 & $88.2 / 180$ & $4.30 / 4.32$ & $23.6 / 22.3$ & $<0.81 /<0.81$ & $6.48 /<4.38$ \\
\hline 4 & $\mathrm{bp} / 17.1$ & $69.1 / 201$ & $3.92 / 4.33$ & $15.7 / 23.3$ & $<0.81 /<0.81$ & $7.76 /<4.38$ \\
\hline 5 & bp / 30.7 & $0.99 / 173$ & $6.04 / 3.92$ & $12.0 / 21.1$ & $<0.81 /<0.81$ & $10.0 /<4.38$ \\
\hline 6 & bp / 39.3 & $106 / 176$ & $3.70 / 4.18$ & $20.4 / 22.3$ & $<0.81 /<0.81$ & $8.40 /<4.38$ \\
\hline 7 & $\mathrm{bp} / 34.3$ & $75.1 / 269$ & $2.70 / 3.89$ & $11.6 / 20.0$ & $<0.81 /<0.81$ & $4.93 /<4.38$ \\
\hline 8 & $\mathrm{bp} / 14.0$ & $83.7 / 147$ & $3.44 / 3.71$ & $13.7 / 26.3$ & $<0.81 /<0.81$ & $7.58 /<4.38$ \\
\hline 9 & bp / 18.9 & $88.2 / 202$ & $4.31 / 4.52$ & $12.7 / 21.0$ & $<0.81 /<0.81$ & $9.04 /<4.38$ \\
\hline 10 & $\mathrm{bp} / 22.6$ & $129 / 247$ & $4.44 / 4.78$ & $17.0 / 23.0$ & $<0.81 /<0.81$ & $11.8 /<4.38$ \\
\hline 11 & bp / 23.9 & $83.2 / 174$ & $4.60 / 5.08$ & $23.2 / 21.6$ & $<0.81 /<0.81$ & $6.91 /<4.38$ \\
\hline 12 & bp / 22.9 & $75.5 / 116$ & $2.66 / 3.78$ & $12.9 / 19.6$ & $<0.81 /<0.81$ & $5.16 /<4.38$ \\
\hline 13 & $\mathrm{bp} / 24.4$ & $91.2 / 168$ & $3.86 / 4.83$ & $14.8 / 20.6$ & $<0.81 /<0.81$ & $5.98 /<4.38$ \\
\hline 14 & bp / 27.6 & $85.2 / 172$ & $6.08 / 4.71$ & $22.6 / 22.4$ & $<0.81 /<0.81$ & $6.80 /<4.38$ \\
\hline 15 & bp / 19.3 & $0.22 / 174$ & $6.08 / 5.60$ & $17.3 / 23.3$ & $<0.81 /<0.81$ & $10.3 /<4.38$ \\
\hline Mean & bp / 24.6 & $71.1 / 183$ & $4.15 / 4.53$ & $16.8 / 22.1$ & $<0.81 /<0.81$ & $7.76 /<4.38$ \\
\hline $\pm S D$ & $-/ 6.54$ & $37.2 / 36.6$ & $1.16 / 0.61$ & $4.62 / 1.63$ & $-1-$ & $2.12 /-$ \\
\hline
\end{tabular}

bp - no increase of the analyte concentration in the exposed algae samples

No increases of cadmium concentrations were determined in all the exposed algae samples. The mean values of metals concentration increases in the exposed algae, determined for the studied reservoirs, demonstrate better sorption characteristics of sea algae for $\mathrm{Mn}, \mathrm{Fe}, \mathrm{Cu}$ and $\mathrm{Zn}$. Fresh water algae Spirogyra sp. showed better lead sorption characteristics. Large values of standard deviation, with regard to the mean value determined for individual reservoirs, illustrate different water pollution levels, depending on the algae exposition location.

Figures 3-5 present the values of determined $R A F$ coefficients (Relation 1) for $\mathrm{Mn}, \mathrm{Fe}$, $\mathrm{Cu}, \mathrm{Zn}$ and $\mathrm{Pb}$. The results presented in the graphs in Figures 3-5 show a differentiated level of metals accumulation in individual reservoirs. The samples of fresh and sea water algae exposed in measurement spots, located along the north side of Turawa reservoir coastline (spots 9-12), show slightly higher heavy metal concentrations compared to the samples exposed along the south side of the lake (spots 1-6) (Fig. 2). These differences may signify the presence of bottom sediments rich in biogenic compounds and heavy metals in the north part of the lake. Higher heavy metals concentrations were confirmed in the algae samples exposed near resorts. Different heavy metals pollution levels in the reservoir waters are confirmed by the in situ studies, carried out with the use of Spirogyra sp., which naturally inhabits this reservoir [15].

The carried out biomonitoring studies with the use of algae showed that waters of the Nysa and Otmuchow reservoirs ecosystem in the Nysa Klodzka river have different levels of heavy metals pollution. The waters flowing into Nysa reservoir (measurement spot 3) are more polluted with heavy metals than the waters flowing out of the reservoir (measurement spot 12). This may signify that heavy metals accumulate in bottom sediments and living organisms. A sample of Spirogyra sp. algae exposed in the measurement spot 10 had the largest concentration of iron and lead. That was because the spot was located near a resort. Similarly, sea algae exposed in that measurement spot showed large concentration of iron. 
a)

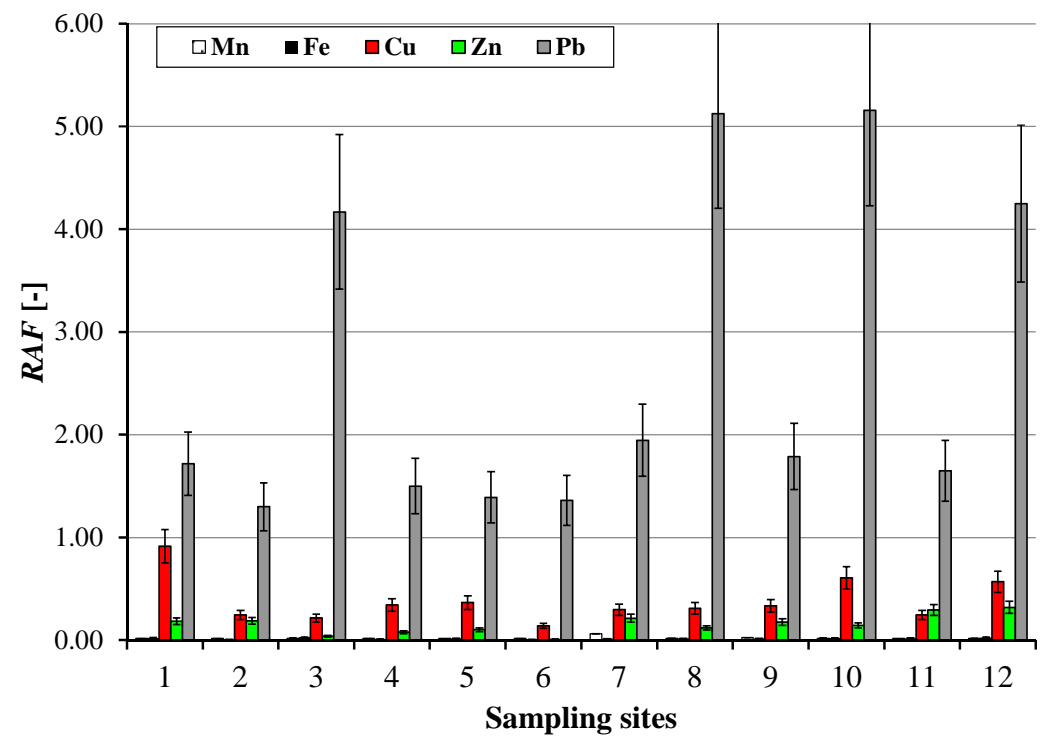

b)

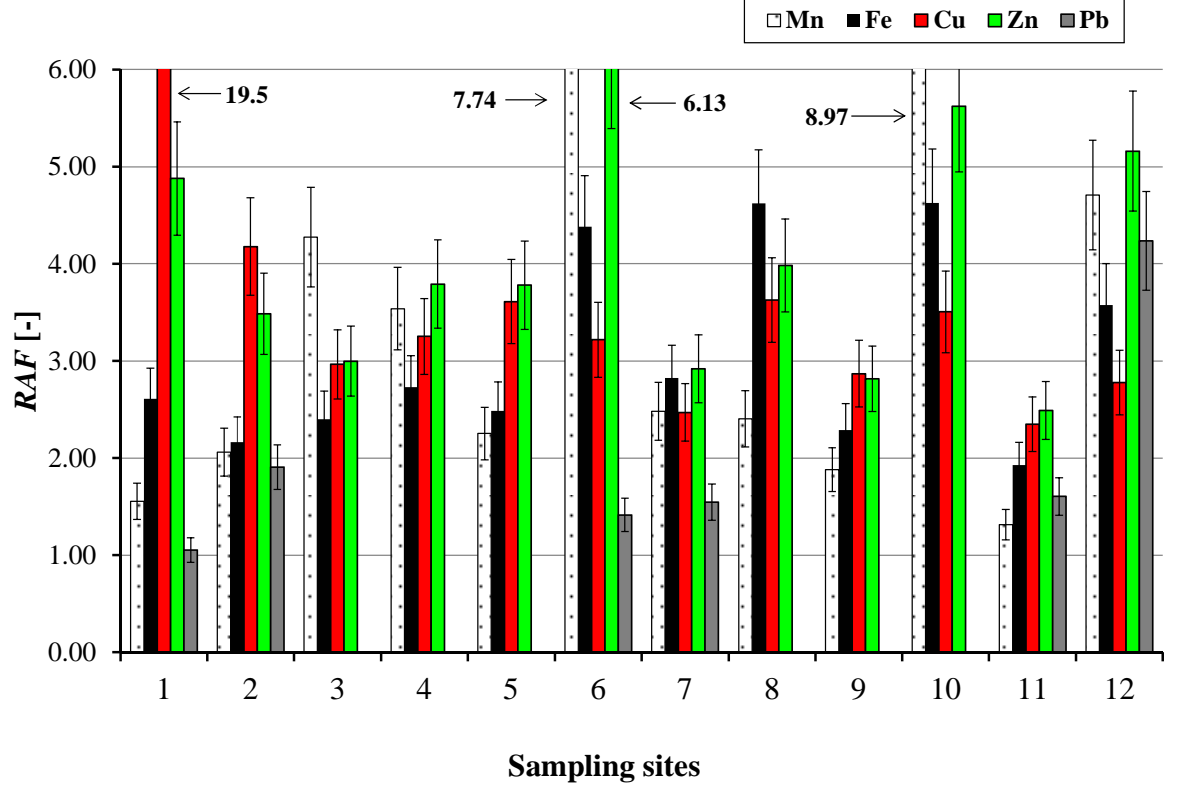

Fig. 3. Increases of heavy metals concentrations in: a) Spirogyra sp. and b) Palmaria palmata exposed in waters of Turawa reservoir 
a)

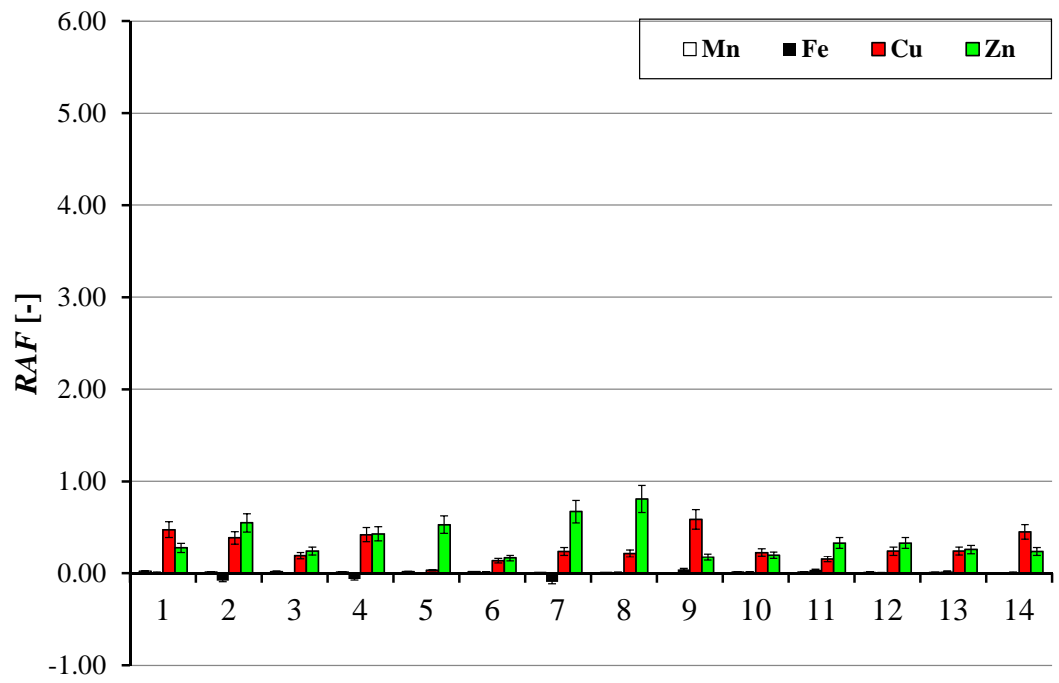

Sampling sites

b)

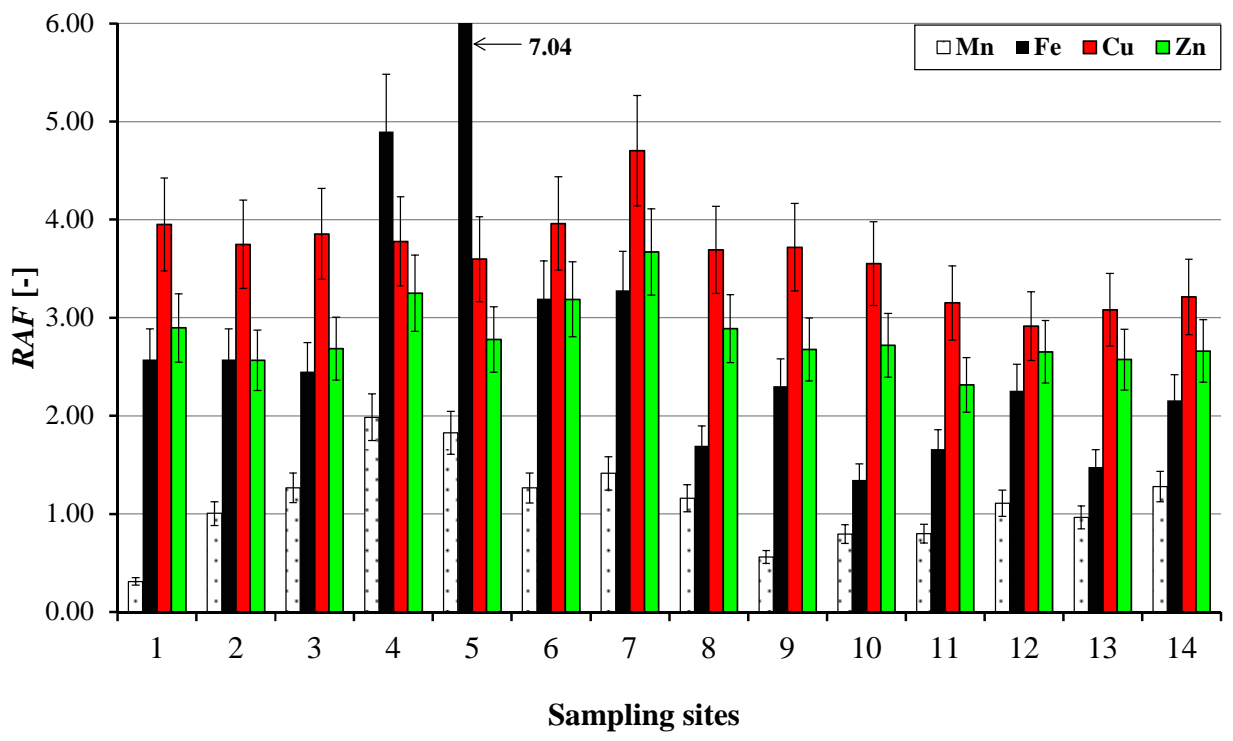

Fig. 4. Increases of heavy metals concentrations in: a) Spirogyra sp. and b) Palmaria palmata exposed in waters of Otmuchow reservoir 


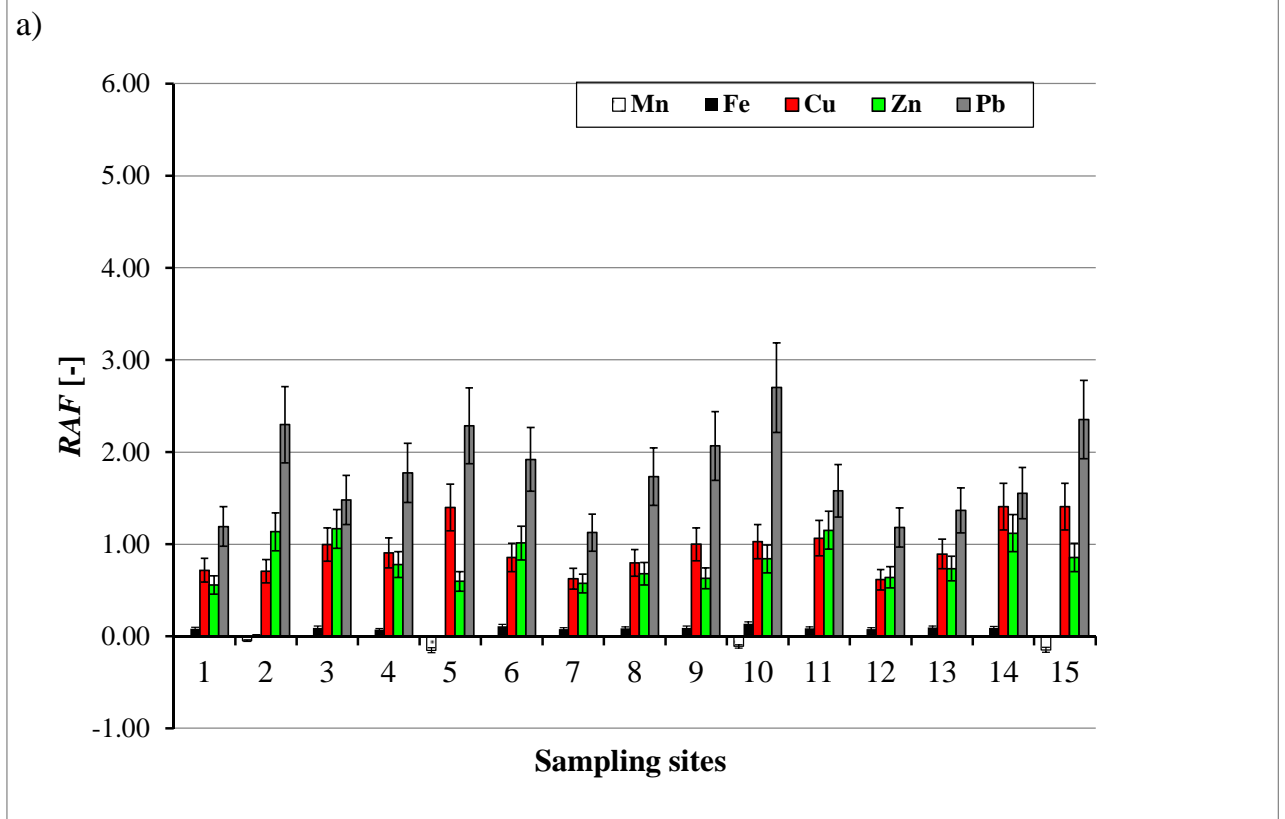

b)

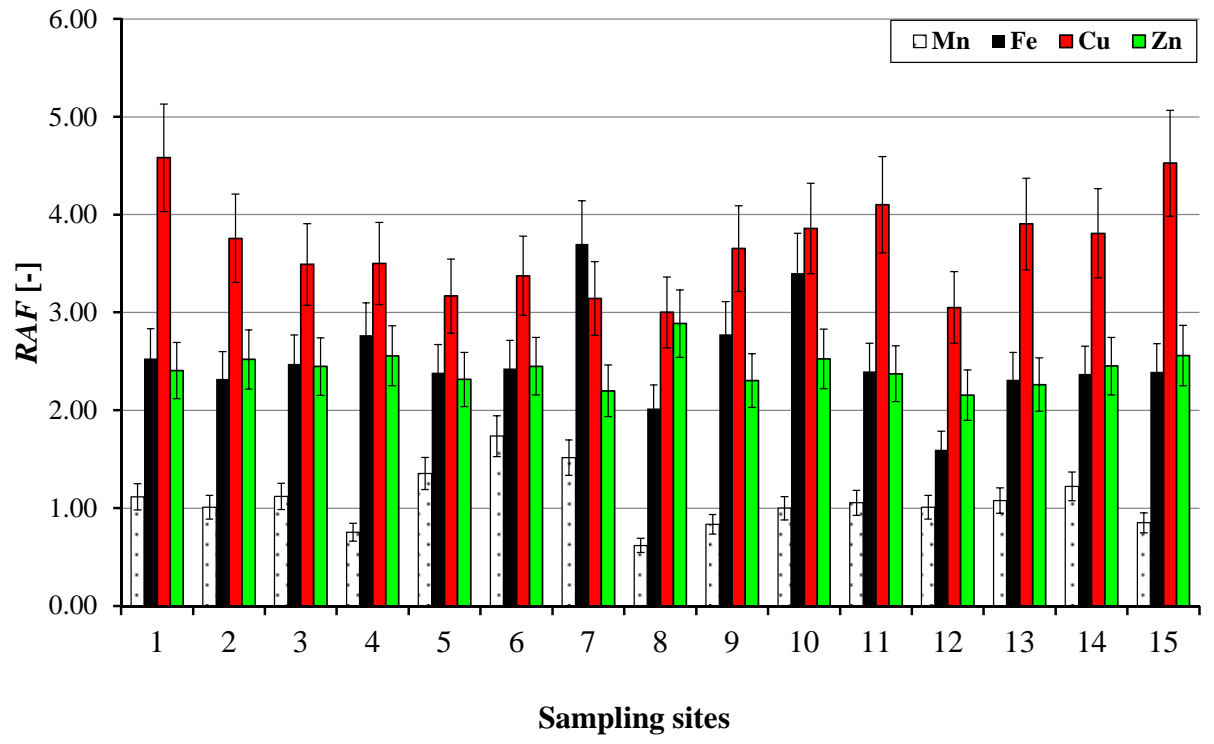

Fig. 5. Increases of heavy metals concentrations in: a) Spirogyra sp. and b) Palmaria palmata exposed in waters of Nysa reservoir

The waters of the Nysa Klodzka river flowing out of Otmuchow reservoir, flow into Nysa reservoir. No statistically relevant differences were determined in concentrations of 
the assessed analytes in the algae exposed in the inlet and outlet from the reservoir. Large concentration of iron was determined in Palmaria palmata algae, exposed in measurement spots 4 and 5, located near a railway track. Large concentrations of zinc were determined both in fresh and sea water algae exposed in measurement spots 7 and 8, located near the state road 46.

Table 6 contains a summary of the calculated coefficient $B C F$ values (Relation 2), showing accumulation characteristics of fresh water Spirogyra sp. and sea water Palmaria palmata algae. $B C F$ coefficients were determined for mean concentrations of heavy metals accumulated in biomass and water.

The values of $B C F>1000$ signify very good heavy metals accumulation characteristics in individual elements of biota $e g$ in water plants [40], zooplankton [41] and in algae [42], and the possibility to use them in biomonitoring and effective phytoremediation.

$B C F$ values calculated for mean concentrations of the analytes accumulated in algae and water

\begin{tabular}{|c|c|c|c|c|c|c|}
\hline Algae & Mn & $\mathbf{F e}$ & $\mathbf{C u}$ & $\mathbf{Z n}$ & Cd & $\mathbf{P b}$ \\
\hline \multicolumn{7}{|c|}{ Turawa reservoir } \\
\hline Spirogyra sp. & 99.4 & 44.3 & $>50.0$ & $>371$ & - & $>163$ \\
\hline $\begin{array}{c}\text { Palmaria } \\
\text { palmata }\end{array}$ & 630 & 596 & $>170$ & $>2684$ & - & - \\
\hline \multicolumn{7}{|c|}{ Otmuchow reservoir } \\
\hline Spirogyra sp. & $>337$ & $>138$ & $>37.6$ & $>938$ & - & - \\
\hline $\begin{array}{c}\text { Palmaria } \\
\text { palmata }\end{array}$ & $>1016$ & $>1603$ & $>136$ & $>1977$ & - & - \\
\hline \multicolumn{7}{|c|}{ Nysa reservoir } \\
\hline Spirogyra sp. & - & $>490$ & $>126$ & $>1200$ & - & $>111$ \\
\hline $\begin{array}{c}\text { Palmaria } \\
\text { palmata } \\
\end{array}$ & $>417$ & $>1262$ & $>137$ & $>1579$ & - & - \\
\hline
\end{tabular}

As demonstrated before, biomass of sea algae Palmaria palmata is a better biosorbent of $\mathrm{Mn}, \mathrm{Fe}, \mathrm{Cu}$ and $\mathrm{Zn}$ in comparison to fresh water algae Spirogyra sp. It should be emphasised that $\mathrm{pH}$ and natural salinity of waters influence the $B C F$ values. The isotherms presented in Figure 2 show the changes in manganese sorption efficiency under the influence of water conductivity.

A comparison of the measured $\left(c^{*}\right)$ and calculated $\left(c^{*}{ }_{o}\right)$ manganese concentrations values in surface waters was carried out, on the basis of relation 3. Palmaria palmata algae were exposed for $50 \mathrm{~min}$. The results are shown in Table 7 . A reminder: $c^{*}=z \cdot c$, where $z$ - cation valence.

Comparison of the measured and calculated values of manganese concentrations in water

\begin{tabular}{|c|c|c|}
\hline Calculated $c^{*}{ }_{o}$ & Measured $c_{z}^{*}$ & $100 \% \cdot\left(c_{0}-c_{\mathrm{z}}\right) / c_{\mathrm{z}}$ \\
\hline \multicolumn{2}{|c|}{$\left[\mathrm{mmol} / \mathrm{dm}^{3}\right]$} & {$[\%]$} \\
\hline 0.0026 & 0.0075 & -65 \\
\hline 0.0060 & 0.0089 & -33 \\
\hline 0.0085 & 0.0068 & 25 \\
\hline 0.0206 & 0.0173 & 19 \\
\hline
\end{tabular}


The study results show that the differences between $c^{*}{ }_{z}$ and $c^{*}{ }_{o}$ decrease together with the increase of manganese concentration in water. The presented data demonstrates that at the current state of the research, the uncertainty of determination of surface waters pollution with the metal, on the basis of the analysis of the composition of Palmaria palmata thallus and measurement of water conductivity, is too large, especially with low concentration of manganese. Studies continue on the influence of conductivity on the algae-solution equilibrium with regard to other metals.

\section{Summary and conclusions}

Research centres are very interested in bioindicators of environment pollution because they are simple and not expensive to obtain. Algae are perceived as one of the main bioindicators of surface waters pollution. Analysis of concentrations of trace elements captured in algae thallus provides much information regarding the pollution introduced to water environment, allows to asses changes in environment quality and to identify the sources of pollution.

On the basis of the carried out research it was demonstrated that Spirogyra sp. and Palmaria palmata algae can be successfully used as biomonitors of water ecosystems pollution with heavy metals. It was also confirmed that biomass from sea algae Palmaria palmata has better sorption characteristics for $\mathrm{Mn}, \mathrm{Fe}, \mathrm{Cu}$ and $\mathrm{Zn}$, compared to fresh water algae Spirogyra sp.

The proposed quantitative method with the use of algae can supplement the qualitative biomonitoring methods. The application of this method is particularly justified in the cases when the allowed pollution quantities, eg heavy metals in surface waters, are lower than the determination level of the applied analytical method.

\section{Acknowledgements}

The Project received financial assistance from the funds of the National Science Centre granted by force of the decision no. DEC-2011/03/D/NZ9/00051.

\section{References}

[1] Chakraborty S, Bhattacharya T, Singh G, Maity JP. Benthic macroalgae as biological indicators of heavy metal pollution in the marine environments: A biomonitoring approach for pollution assessment. Ecotoxicol Environ Safety. 2014;100(1):61-68. DOI: 10.1016/j.ecoenv.2013.12.003.

[2] Bhatnagar M, Bhardwaj N. Biodiversity of algal flora in River Chambal at Kota, Rajasthan. Nature Environ Pollut Technol. 2013;12(3):547-549.

[3] Rajfur M. Algae - heavy metals biosorbent. Ecol Chem Eng S. 2014;20(1):23-40. DOI: 10.2478/eces-20130002 .

[4] Hollar S, editor. A Closer at Bacteria, Algae, and Protozoa. New York: Britannica Educational Publishing; 2012.

[5] Bellinger GE, Sigee CD. Freshwater Algae. Identification and Use as Bioindicators. Chichester: John Wiley \& Sons; 2010.

[6] Barsanti L, Gualtieri P. Algae. Anatomy, Biochemistry and Biotechnology. Boca Raton: Taylor \& Francis; 2006.

[7] Benkdad A, Abdelmourhit L, Tornero VM, Benmansour M, Chakir E, Garrido MI, et al. Trace metals and radionuclides in macroalgae from Moroccan coastal waters. Environ Monit Assess. 2011;182:317-324. DOI: 10.1007/s10661-011-1878-0. 
[8] Brito GB, de Souza TL, Bressy FC, Moura CWN, Korn MGA. Levels and spatial distribution of trace elements in macroalgae species from the Todos os Santos Bay, Bahia, Brazil. Marine Pollut Bull. 2012;64:2238-2244. DOI: 10.1016/j.marpolbul.2012.06.022.

[9] Malea P, Kevrekidis T. Trace element patterns in marine macroalgae. Sci Total Environ. 2014;494-495:144-157. DOI: 10.1016/j.scitotenv.2014.06.134.

[10] Pandeya LK, Kumarb D, Yadava A, Raia J, Gaur JP. Morphological abnormalities in periphytic diatoms as a tool forbiomonitoring of heavy metal pollution in a river. Ecol Indicators. 2014;36:272-279. DOI: 10.1016/j.ecolind.2013.08.002.

[11] Rai UN, Prasad D, Verma S, Upadhyay AK, Singh NK. Biomonitoring of metals in Ganga Water at different ghats of haridwar: Implications of constructed wetland for sewage detoxification. Bull Environ Contam Toxicol. 2012;89:805-810. DOI: 10.1007/s00128-012-0766-9.

[12] Chakraborty S, Bhattacharya T, Singh G, Maity JP. Benthic macroalgae as biological indicators of heavy metal pollution in the marine environments: A biomonitoring approach for pollution assessment. Ecotoxicol Environ Safety. 2014;100:61-68. DOI: 10.1016/j.ecoenv.2013.12.003.

[13] Hédouin L, Bustamante P, Fichez R, Warnau M. The tropical brown alga Lobophora variegata as a bioindicator of mining contamination in the New Caledonia lagoon: A field transplantation study. Marine Environ Res. 2008;66:438-444.

[14] Zielińska M, Rajfur M, Kozłowski R, Kłos A. Biomonitoring aktywny rzeki Odry z wykorzystaniem glonów Palmaria palmata. Proc. ECOpole. 2013;7(2):756-763. DOI: 10.2429/proc.2013.7(2)099.

[15] Rajfur M, Kłos A, Wacławek M. Application of alga in biomonitoring of the Large Turawa Lake. Int J Environ Sci Health. 2011;46(12):1401-1408. DOI:10.1080/10934529.2011.606717.

[16] Żbikowski RZ, Szefer P, Latała A. Distribution and relationships between selected chemical elements in green alga Enteromorpha sp. from the southern Baltic. Environ Pollut. 2006;143:435-448.

[17] Żbikowski RZ, Szefer P, Latała A. Comparison of green algae Cladophora sp. and Enteromorpha sp. as potential biomonitors of chemical elements in the southern Baltic. Sci Total Environ. 2007;387:320-332.

[18] Žáková Z, Kočková E. Biomonitoring and assessment of heavy metal contamination of streams and reservoirs in the Dyje/Thaya river basin, Czech Republic. Water Sci Tech. 1999;39(12):225-232. DOI: 10.1016/S0273-1223(99)00339-X.

[19] Komulainent SF, Morozov AK. Heavy metal dynamics in the periphyton in small rivers of Kola Peninsula. Water Res. 2010;37(6):874-878. DOI: 10.1134/S0097807810060138.

[20] Anishchenko OV, Gladyshev MI, Kravchuk ES, Ivanova EA, Gribovskaya IV, Sushchik NN. Seasonal variations of metal concentrations in periphyton and taxonomic composition of the algal community at a Yenisei River littoral site. Central Europ J Biology. 2010;5(1):125-134. DOI: 10.2478/s11535-009-0060-y.

[21] Grosheva EI, Voronskaya GN, Pastukhove MV. Trace element bioavailability in Lake Baikal. Aquatic Ecosystem Health Manage. 2000;3:229-234.

[22] Chernova EN, Khristoforova NK, Vyshkvartsev DI. Heavy metals in seagrasses and algae of Pos'et Bay, Sea of Japan. Russ J Marine Biol. 2002;28(6):387-392.

[23] Ho YB. Ulva lactuca as bioindicator of metal contamination in intertidal waters in Hong Kong. Hydrobiologia. 1990;230(1-2):73-81. DOI: 10.1007/BF00005615.

[24] Ho YB. Metals in Ulva lactuca in Hong Kong intertidal waters. Bull Marine Sci. 1990;47(1):79-85.

[25] Coelho JP, Pereira ME, Duarte A, Pardal MA. Macroalgae response to a mercury contamination gradient in a temperate coastal lagoon (Ria de Aveiro, Portugal). Estuarine, Coastal Shelf Sci. 2005;65:492-500.

[26] Market B, Pedrozo F, Geller W, Friese K, Korhammer S, Baffico G, et al. A contribution to the study of the heavy-metal and nutritional element status of some lakes in the southern Andes of Patagonia (Argentina). Sci Total Environ. 1997;206:1-15.

[27] Lwanga MS, Kansiime F, Denny P, Scullion J. Heavy metals in Lake George, Uganda, with relation to metal concentrations in tissues of common fish species. Hydrobiologia. 2003;499:83-93. DOI: 10.1023/A:1026347703129.

[28] Sekabira K, Origa HO, Basamba TA, Mutumba G, Kakudidi E. Application of algae in biomonitoring and phytoextraction of heavy metals contamination in urban stream water. Int $\mathbf{J}$ Environ Sci Technol. 2011;8(1):115-128. DOI: 10.1007/BF03326201.

[29] Ndiokwere CL. An investigation of the heavy metal content of sediments and algae from the River Niger and Nigerian Atlantic coastal waters. Environ Pollut. 1984;7(4):247-254. DOI: 10.1016/0143$148 X(84) 90040-5$. 
[30] Gomes PIA, Asaeda T. Phytoremediation of heavy metals by calcifying macro-algae (Nitella pseudoflabellata): Implications of redox insensitive end products. Chemosphere. 2013;92(10):1328-1334. DOI: 10.1016/j.chemosphere.2013.05.043.

[31] Vijayaraghavan K, Joshi UM. Hybrid Sargassum-sand sorbent: A novel adsorbent in packed column to treat metal-bearing wastewaters from inductively coupled plasma-optical emission spectrometry. J Environ Sci Health - Part A Toxic/Hazard Substances Environ Eng. 2013;48(13):1685-1693. DOI: 10.1080/10934529.2013.815503.

[32] Zwoliński G, Dura K. Jeziora Turawskie, wschodnie okolice Opola. Wrocław: Studio Wyd. PLAN; 2006.

[33] Badora K, Gontarek M, Kuńka A, Nowak A, Nowak S, Spałek K. Przyroda powiatu opolskiego. Opole: Oficyna Piastowska; 2003.

[34] Koziarski S, Makowiecki J. Walory przyrodniczo-krajobrazowe Otmuchowsko-Nyskiego Obszaru Chronionego Krajobrazu. Opole: Uniwersytet Opolski; 2001.

[35] Rajfur M, Kłos A, Wacławek M. Sorption of copper(II) ions in the biomass of alga Spirogyra sp. Bioelectrochemistry. 2012;87:65-70. DOI:10.1016/j.bioelechem.2011.12.007.

[36] Instrukcja obsługi aparatu AAS iCE 3000 firmy Thermo Scientific. Warszawa: Spectro-Lab; 2013.

[37] Ahmad A, Ghufran R, Zularisam AW. Phytosequestration of metals in selected plants growing on a contaminated Okhla Industrial Areas, Okhla, New Delhi, India. Water Air Soil Pollut. 2011;217:255-266. DOI: 10.1007/s11270-010-0584-9.

[38] Yang J, Li H, Ran Y, Chan K. Distribution and bioconcentration of endocrine disrupting chemicals in surface water and fish bile of the Pearl River Delta, South China. Chemosphere. 2014;107:439-446. DOI: 10.1016/j.chemosphere.2014.01.048.

[39] Rozporządzenie Ministra Środowiska z dnia 9 listopada 2011 r. w sprawie sposobu klasyfikacji stanu jednolitych części wód powierzchniowych oraz środowiskowych norm jakości dla substancji priorytetowych - Prawo wodne (DzU Nr 239, poz. 2019).

[40] Fawzy MA, El-Sayed Badr N, El-Khatib A, Abo-El-Kassem A. Heavy metal biomonitoring and phytoremediation potentialities of aquatic macrophytes in River Nile. Environ Monit Assess. 2012;184:1753-1771. DOI: 10.1007/s10661-011-2076-9.

[41] Nguyen LH, Leermakers M, Elskens M, Ridder DF, Doan HT, Baeyens W. Correletions, partitioning and bioaccumulation of heavy metals between different compartments of Lake Balaton. Sci Total Environ. 2005;341:211-226.

[42] Anwar A, Ghufran R, Zularisam AW. Phytosequestration of metals in selected plants growing on a contaminated Okhla Industrial Areas, Okhla, New Delhi, India. Water Air Soil Pollut. 2011;217:255-266. DOI: $10.1007 / \mathrm{s} 11270-010-0584-9$.

\title{
ZASTOSOWANIE GLONÓW W BIOMONITORINGU AKTYWNYM WÓD POWIERZCHNIOWYCH
}

\author{
Samodzielna Katedra Biotechnologii i Biologii Molekularnej, Uniwersytet Opolski
}

\begin{abstract}
Abstrakt: Przeprowadzono badania biomonitoringowe trzech zbiorników retencyjnych położonych na terenie województwa opolskiego (południowa Polska): Zbiornika Turawa, Zbiornika Nysa i Zbiornika Otmuchów. W glonach słodkowodnych Spirogyra sp. i morskich Palmaria palmata (Linnaeus) Weber \& Mohr, eksponowanych w badanych wodach, oznaczono metodą absorpcyjnej spektrometrii atomowej (AAS) przyrosty stężeń: $\mathrm{Mn}, \mathrm{Fe}, \mathrm{Cu}, \mathrm{Zn}, \mathrm{Cd}$ i Pb. W wodach oznaczano także pH, konduktywność oraz stężenie Mn i Fe. Stężenia $\mathrm{Cu}, \mathrm{Zn}, \mathrm{Cd}$ i $\mathrm{Pb}$ w badanych wodach były mniejsze od granicy oznaczalności metody. Badania prowadzono od czerwca do lipca 2014 r. Wskazano na różnice w przyrostach stężeń metali ciężkich w próbkach glonów eksponowanych wzdłuż linii brzegowej, co wynika z różnej odległości od źródeł zanieczyszczeń, którymi mogą być osady denne lub odcieki z terenów przylegających do zbiorników. Wskazano także na lepsze właściwości sorpcyjne glonów Palmaria palmata w porównaniu z glonami Spirogyra sp. Przetestowano również empiryczną zależność, której zastosowanie po modyfikacji może umożliwić ilościową ocenę zanieczyszczenia wód metalami ciężkimi na podstawie analizy stężenia tego pierwiastka w plechach glonów.
\end{abstract}

Słowa kluczowe: glony, Spirogyra sp., Palmaria palmata (Linnaeus) Weber \& Mohr, metale ciężkie, biomonitoring, zbiorniki retencyjne 